\title{
Short-Term Disturbance Effects of Outdoor Education Stream Classes on Aquatic Macroinvertebrates
}

\author{
Jon P. Bossley ${ }^{1,2}$, Peter C. Smiley Jr. ${ }^{3}$ \\ ${ }^{1}$ Environmental Science Graduate Program, The Ohio State University, Columbus, OH, USA \\ ${ }^{2}$ School of Natural and Social Sciences, Mount Vernon Nazarene University, Mount Vernon, OH, USA \\ ${ }^{3}$ USDA Agricultural Research Service, Soil Drainage Research Unit, Columbus, OH, USA \\ Email: jon.bossley@mvnu.edu
}

How to cite this paper: Bossley, J.P. and Smiley Jr., P.C. (2017) Short-Term Disturbance Effects of Outdoor Education Stream Classes on Aquatic Macroinvertebrates. Journal of Environmental Protection, 8, 1333-1353. https://doi.org/10.4236/jep.2017.811082

Received: September 12, 2017

Accepted: October 27, 2017

Published: October 30, 2017

Copyright $\odot 2017$ by authors and Scientific Research Publishing Inc. This work is licensed under the Creative Commons Attribution International License (CC BY 4.0).

http://creativecommons.org/licenses/by/4.0/

(c) (i) Open Access

\begin{abstract}
Outdoor education programs frequently offer stream classes that teach students how to assess water quality based on the composition of aquatic macroinvertebrate communities. Repeatedly using the same site for stream classes can cause disturbance that could negatively impact aquatic macroinvertebrates. However, the impact of outdoor education stream classes on short term temporal trends of aquatic macroinvertebrates has not been evaluated. Our objective was to quantify whether outdoor education stream classes caused localized and short-term impacts on the aquatic macroinvertebrate community. We sampled aquatic macroinvertebrates over a five day period in May 2014 from an impacted riffle subjected to repeated substrate disturbance by outdoor education stream classes and an unimpacted riffle that was not subjected to stream classes within an agricultural stream in central Ohio. We did not observe a difference in macroinvertebrate community response variables between different time periods or among days within the impacted riffle as part of our within riffle analysis. We documented that macroinvertebrate abundance and dorsoventrally flattened clinger abundance was greater within the unimpacted riffle than the impacted riffle. Macroinvertebrate evenness was greater in the impacted riffle than the unimpacted riffle. In the impacted riffle percent clingers was greater on Monday than on Friday. Conversely, in the unimpacted riffle percent clingers was greater on Friday than on Monday. Our results indicated that outdoor education stream classes did not alter short term temporal trends of macroinvertebrate community structure within an impacted riffle, but the stream classes resulted in differences in community structure between an impacted and unimpacted riffle. Our results suggest that outdoor
\end{abstract}


education centers should avoid repeatedly using the same site for their stream classes to prevent negatively impacting aquatic macroinvertebrates.

\section{Keywords}

Substrate Disruption, Trampling, Macroinvertebrate Community, Riffles

\section{Introduction}

Time and change are continuous processes in any ecosystem, but their influence is accelerated in highly dynamic ecosystems like streams. Disturbance plays a major role in determining the population, community, and ecosystem structure and dynamics of streams [1]. Disturbance has been defined as "any relatively discrete event in time that disrupts ecosystem, community, or population structure and changes resources, substrate availability, or the physical environment" [2]. While a press disturbance (e.g., logging, chemical pollutants within stream sediments) may affect lotic ecosystems continuously for months or years, pulse disturbances (e.g., spates) can periodically impact lotic ecosystems relatively quickly (i.e., hours, days, or weeks) [3]. Chemical disturbances as a result of agricultural runoff or industrial waste and physical disturbances from floods, construction projects, and land-use changes have received much attention in the literature [1] [3]. A newer body of literature has begun to evaluate the influence of disturbance caused by human recreational activity within natural areas on the biota [4] [5] [6] [7] [8]. In addition to considering the disturbance impacts of ecotourism and outdoor recreation, it is important to recognize that outdoor education programs may also cause disturbance to the biota.

Outdoor education is a popular, hands-on educational method conducted at outdoor sites and aimed at fostering appreciation for nature among school children. Many camps, nature centers, and parks offer outdoor education stream classes that often involve a focus on assessing water quality based on the abundance and diversity of pollution sensitive aquatic macroinvertebrates [9]. Instructors of stream classes typically encourage students to move and flip rocks within the streambed in search of aquatic macroinvertebrates. Additionally, outdoor education organizations typically use the same stream and often the same site for their stream classes as a result of familiarity, ease of access, and safety considerations. Subsequently, over the course of a year the same stretch of stream may be subjected to substrate disruption by extensive student activity. The influence of outdoor education stream classes on stream macroinvertebrates has not been documented previously. Understanding the ecological responses of stream macroinvertebrates to human instream activity as a result of stream classes is needed to help outdoor education centers, nature centers, and parks sustainably manage the streams that they use for their educational programs [10] [11].

Insights to the potential effects of outdoor education stream classes on stream 
macroinvertebrates can be found in previous studies examining the influence of scientific collecting and outdoor recreational activities on stream macroinvertebrates. Falk [12] discussed the bias that researchers may introduce into a field study by collecting and vouchering specimens and argued that researchers in effect become a new top predator in the ecosystem. Three studies [13] [14] [15] examined the effects of outdoor recreation activities on aquatic macroinvertebrates and found evidence of reduced macroinvertebrate density [13], reduced macroinvertebrate abundance [14], reduced taxa richness [14], and increased catastrophic drift [15] in response to instream recreational activities by humans. These studies demonstrate that human activity may act as a pulse disturbance by causing substrate movement thereby inducing drift, injury, or death to stream macroinvertebrates. Additionally, the frequent, repetitive usage of the same stream site over weeks, months, or years by outdoor education programs may act as a press disturbance.

We examined the effects of daily disturbance caused by repetitive activity of students participating in outdoor education stream classes on stream macroinvertebrates within an agricultural stream in central Ohio. This study is one of four studies conducted at multiple spatial and temporal scales from 2013 to 2015 to quantify the influence of outdoor education stream classes on aquatic macroinvertebrates [16]. In this manuscript we document the results of the study designed to examine the localized, short-term disturbance effects of outdoor education stream classes on aquatic macroinvertebrates, and to our knowledge this is the first study to do so. Previous studies have found that aquatic macroinvertebrates can recover quickly following a physical disturbance in as little as three days [17] [18] [19]. As a result we believed an evaluation of the short term impacts of stream classes was needed to complement the findings of our longer term studies. Specifically, we investigated whether differences in the aquatic macroinvertebrate community occurred between time periods and among days over a five day period within a riffle repeatedly subjected to outdoor education stream classes. We also evaluated whether differences in the aquatic macroinvertebrate community occurred between a riffle repeatedly subjected to outdoor education stream classes and an unimpacted upstream riffle over a five day period. Our objective was to quantify whether outdoor education stream classes negatively impacted the aquatic macroinvertebrate community between time periods within a day (morning and afternoon) or among days. We predicted that the macroinvertebrate community will exhibit a negative response (i.e., declines in abundance, richness, diversity, and changes in the abundance of select guilds) to daily student activity that increases as the week progresses within an impacted riffle subjected to repeated disturbance by outdoor education classes. We also predicted that the macroinvertebrate community in the impacted riffle will exhibit a negative response to repeated disturbance by outdoor education stream classes over a five day period, while the macroinvertebrate community in the unimpacted riffle will remain unchanged by student activity. 


\section{Methods}

\subsection{Study Area and Sampling Sites}

Our study was conducted at two riffles within the portion of the upper Alum Creek that flows through the grounds of the Heartland Outdoor School in central Ohio. The upper Alum Creek is a fourth order stream at Heartland Outdoor School, which is an outdoor education center providing overnight/multi-day hands-on nature and environmental science programs for K-12 students. The impacted riffle $\left(40^{\circ} 23^{\prime} 01.014^{\prime \prime} \mathrm{N}, 82^{\circ} 52^{\prime} 37.870^{\prime \prime} \mathrm{W}\right)$ is a $7 \mathrm{~m}$ long riffle that has been used as part of stream classes taught by the Heartland Outdoor School since 2010. The impacted riffle is characterized by a forested riparian buffer (riparian width $>30.5 \mathrm{~m}$ ) with an agricultural field bordering the riparian buffer on the right bank. Alum Creek at this site is a C-4 riffle-pool stream [20] with moderate sinuosity (1.3), no constrictions, broad confinement ratio $(>10)$, and substrate composed primarily of coarse gravel (D50 $=38 \%$ coarse gravel substrate). The impacted riffle is the focal point for students in the stream study program that receives an average of 6000 participants annually. Stream classes are held in the impacted riffle in the spring (April to June) and autumn (September to November). Students learn that Group 1 pollution-sensitive macroinvertebrates that serve as indicators of water quality prefer the highly oxygenated waters and heterogeneous substrate of the riffle [9] [21]. As a result of student exploration and collecting efforts the impacted riffle experiences greater foot traffic, greater incidence of rock-turning, and greater levels of substrate movement compared to other nearby channel units and the upstream unimpacted riffle [16]. We also sampled aquatic macroinvertebrates from an unimpacted riffle $\left(40^{\circ} 23^{\prime} 02.662^{\prime \prime} \mathrm{N}, 82^{\circ} 52^{\prime} 36.171^{\prime \prime} \mathrm{W}\right)$ that is $7 \mathrm{~m}$ long and located $91 \mathrm{~m}$ upstream of the impacted riffle to enable a between-riffles comparison as part of our study. The unimpacted riffle exhibits riparian, geomorphic, and substrate characteristics similar to the impacted riffle, but it has never been used as part of Heartland Outdoor School's stream classes. The absence of stream classes within the unimpacted riffle results in it experiencing little or no human foot traffic, rock-flipping, and substrate movement [16].

We conducted our study from 19 May 2014 to 23 May 2014, which corresponds to the dates that Heartland Outdoor School receives the largest school groups (based on enrollment numbers) during its academic year. These dates represent the seventh week in which stream classes were offered in the spring and 447 students participated in 19 individual stream classes at the impacted riffle during the study. We anticipated that if student instream activity can induce short-term disturbance, it was most likely to be evident during this week. The warm weather in May is conducive for stream classes and, consequently, the stream class program annually experiences its greatest level of participation in May. Previous research findings [16] indicated that activity, abundance, and taxa richness of the resident macroinvertebrate community in this stream are also 
greatest during spring, making this season ideal for evaluating the influence of stream classes. The mean daily discharge levels at the USGS gauge located 5.6 $\mathrm{km}$ downstream of the impacted riffle during our study was $3.5 \mathrm{~m}^{3} / \mathrm{sec}$ with a minimum of $2.2 \mathrm{~m}^{3} / \mathrm{sec}$ and a maximum of $7.0 \mathrm{~m}^{3} / \mathrm{sec}$, indicating safe conditions for stream classes to proceed on schedule.

\subsection{Within-Riffle Assessment}

The objective for this assessment was to determine if the aquatic macroinvertebrate community within the impacted riffle differed between time periods (morning and afternoon) and among days during the week. Our sampling schedule was based on the Heartland Outdoor School's typical daily class schedule for the busy spring season (Table 1). Students typically arrive at the school on Monday morning and begin their slate of classes early in the afternoon. To ensure that all students have opportunity to take the stream class, the typical schedule rotation incorporates five stream classes per day. Two stream classes are conducted in the morning, three stream classes in the afternoon, and one stream class in the evening from Tuesday through Thursday. Friday stream classes are limited to the morning before the students return home. Following this schedule, morning samples for the within-riffle assessment were collected starting at 9:30 am EDT on Monday. From Tuesday to Thursday, morning samples were collected between 7:00-8:30 am EDT prior to the first stream classes for each day. Afternoon samples from Tuesday to Thursday were collected between 2:30-4:30 pm EDT after most afternoon stream classes were completed. The school group in session during the week of our study had an early departure time on Friday. Consequently, Friday morning samples for the within-riffle study were taken prior to 7:30 am EDT and the post-class samples were taken starting shortly after 11:00 am EDT. Within this sampling schedule our morning samples represented the condition of aquatic communities before daily disturbance (i.e., prior to the first stream classes of the day) and our afternoon samples represented the condition of the aquatic macroinvertebrates after daily disturbance (i.e., after stream classes were conducted).

A random sampling grid of $301 \mathrm{~m}^{2}$ quadrats was set up over half of the riffle

Table 1. Typical stream class schedule used by Heartland Outdoor School from mid-April to early June of 2014 showing daily class times and a continuous count of stream classes for the week.

\begin{tabular}{cccccc}
\hline Class Time & Monday & Tuesday & Wednesday & Thursday & Friday \\
\hline 9:15-10:15 am & & Class 4 & Class 9 & Class 14 & Class 19 \\
10:30-11:30 am & & Class 5 & Class 10 & Class 15 & Class 20 \\
1:30-2:30 pm & Class 1 & Class 6 & Class 11 & Class 16 & \\
2:45-3:45 pm & Class 2 & Class 7 & Class 12 & Class 17 & \\
6:30-7:30 pm & Class 3 & Class 8 & Class 13 & Class 18 & \\
\hline
\end{tabular}


along the left bank where students enter the stream. If student-induced disturbance occurs, its effects were expected to be greater and more likely to be revealed in this half of the riffle because of the greater foot traffic. The random sampling grid ensured random selection of samples within the riffle, ensured representative sampling from three longitudinal sections (i.e., upstream, middle, and downstream sections) of the riffle, and avoided repeat sampling of the same quadrat.

Aquatic macroinvertebrates were collected via Surber sampler (500 $\mu \mathrm{m}$ net; $30.5 \mathrm{~cm} \times 30.5 \mathrm{~cm}$ frame) with the substrate disturbed by hand with the aid of a screwdriver for 30 seconds to a depth of $10 \mathrm{~cm}$ or to an impenetrable hard layer (whichever was encountered first). To ensure representative sampling from the entire riffle length, one sample was collected from a randomly determined quadrat within each of three sections of the riffle during each sampling period. The three riffle sections included upper riffle (i.e., the two upstream rows in the sampling grid), mid riffle (i.e., the two rows in the middle of the riffle), and lower riffle (i.e., the two rows at the downstream end of the riffle). All three samples were collected consecutively beginning downstream and working upstream. Thus, we collected three randomly located Surber samples from the riffle each time period each day resulting in six samples collected each day and a total of 30 samples collected for the entire week.

Identification of live aquatic macroinvertebrates in each sample commenced immediately upon completion of sampling. Samples were individually transferred to a large picking pan and identified to phylum, class, order, or family taxonomic resolution with the aid of a Nikon (20x) dissection microscope. Organisms identified at phylum, class, order, or sub-order taxonomic resolution included non-insects (Collembola, Hydracarina, Nematoda, Oligochaeta, Turbellaria) and insects (Anisoptera, Zygoptera, Hemiptera, Plecoptera). Family-level identification was used for some non-insects (Asellidae, Cambaridae, Pleuroceridae, Sphaeridae) and most insect taxa (Psephenidae, Elmidae, Simuliidae, Ceratopogonidae, Chaoboridae, Chironomidae, Tipulidae, Baetidae, Caenidae, Heptageniidae, Isonychiidae, Leptophlebiidae, Helicopsychidae). All organisms from each sample were returned to the quadrat from which they were taken immediately after identification. The catch and release protocol was used to allow the macroinvertebrates an opportunity to recolonize the quadrat from which they were taken and safeguard against the investigators introducing additional disturbance by permanently removing specimens from the stream [12]. Our field identification and subsequent release of live animals prohibited the use of a finer scale taxonomic resolution to either genus or species level.

\subsection{Between-Riffle Assessment}

Our objective for this assessment was to determine if aquatic macroinvertebrate communities differed between the start of sampling on Monday and end of sampling on Friday (Monday and Friday) and between riffles (impacted riffle and 
unimpacted riffle). We also established a random sampling grid of $301 \mathrm{~m}^{2}$ quadrats over half of the unimpacted riffle along the right stream bank. This portion of the unimpacted riffle was selected because it was physically similar to the impacted riffle. We sampled aquatic macroinvertebrates with a Surber sampler using the same sampling methods as described above within the unimpacted riffle. The quadrats within the unimpacted riffle that were selected for macroinvertebrate sampling were based on the quadrat numbers that were randomly selected for sampling within the impacted riffle. This ensured our samples were randomly selected and ensured comparability between the two riffles. The first samples from the unimpacted riffle were collected on Monday beginning at 11:45 am EDT and the last samples were collected on Friday afternoon starting at 12:00 pm EDT. Additionally, after identification all macroinvertebrates were released alive within the quadrat from which they were captured.

\subsection{Statistical Analysis}

We assessed macroinvertebrate community structure with nine response variables: 1) macroinvertebrate abundance (number of macroinvertebrates captured in each sample); 2) taxa richness (number of taxa represented in each sample); 3) EPT abundance (number of Ephemeroptera, Plecoptera, and Trichoptera captured in each sample); 4) clinger abundance (number of macroinvertebrates in the clinger habit guild including families Elmidae, Heptageniidae, Baetidae, Helicopsychidae, Glossosomatidae, Hydropsychidae, Philopotamidae, Polycentropodidae, Psephenidae, Simuliidae); 5) dorsoventrally flattened (DVF) clinger abundance (number of Heptageniidae and Psephenidae captured in each sample); 6) percent EPT (percent composition of EPT calculated as EPT abundance divided by macroinvertebrate abundance); 7) Shannon diversity [22]; 8) evenness (calculated as $\mathrm{E}_{1 / \mathrm{D}}$ ) [23]; and 9) percent clingers (percent composition of clinger macroinvertebrates calculated as clinger abundance divided by macroinvertebrate abundance).

These nine response variables were chosen to encompass a range of community response variables that would ensure a robust evaluation of the riffle community. Macroinvertebrate abundance and taxa richness were included to examine whether stream classes can reduce the number of macroinvertebrates or eliminate certain taxa. Macroinvertebrate abundance and taxa richness are of immediate importance to outdoor education stream classes because greater abundance enables better opportunity for students to catch macroinvertebrates and greater taxa richness provides better opportunity for students to catch a variety of macroinvertebrate types. Shannon diversity and evenness were chosen on the basis of their robustness and wide usage as measures of diversity and evenness. EPT response variables were included because of the known sensitivity to disturbance exhibited by EPT taxa. The three clinger response variables (clinger abundance, percent clingers, and DVF clinger abundance) were selected because we anticipated that clingers would be tolerant of the substrate disturbance caused 
by stream classes because their dorsoventrally flattened bodies and tarsal claws would enable them to maintain position on the substrate with the occurrence of disturbance.

We used R statistical software [24] and a level of significance of 0.05 for all statistical analyses. For the within-riffle analysis, we used a two factor generalized linear model analysis with the quasi-Poisson distribution and the glm function [24] to determine if whole integer response variables based on count data (macroinvertebrate abundance, taxa richness, EPT abundance, clinger abundance, DVF clinger abundance) differed between time periods (i.e., morning and afternoon) or among days during the week. We also conducted a two factor analysis of variance with the $\mathrm{lm}$ function [24] to determine if non-whole integer response variables (Shannon diversity, evenness, percent clingers, percent EPT) differed between time periods or among days within the impacted riffle. Examination of the normal q-q plots with the qqPlot function in the car package [25] for these four response variables confirmed that their distributions did not differ from the normal distribution.

For the between-riffles analysis, we used a two factor generalized linear model analysis with the quasi-Poisson distribution and the glm function [24] to determine if whole integer response variables based on count data (macroinvertebrate abundance, taxa richness, EPT abundance, clinger abundance, DVF clinger abundance) differed between days (i.e., the start of sampling on Monday morning and the end of sampling on Friday afternoon) and sites (impacted and unimpacted riffles). We also used a two factor analysis of variance and the $\operatorname{lm}$ function [24] to determine if non-whole integer response variables (Shannon diversity, evenness, percent clingers, percent EPT) differed between days and sites. Examination of the normal q-q plots with the qqPlot function in the car package [25] for these four response variables confirmed that their distributions did not differ from the normal distribution.

\section{Results}

Within the impacted riffle we documented 25 taxa from 988 captures over five days of sampling. The three most abundant taxa captured were Nematoda, Chironomidae, and Baetidae (Table 2). For the within-riffle analysis, no differences $(\mathrm{P}>0.05)$ in the nine macroinvertebrate response variables occurred between time periods or among days (Table 3 ). Additionally, none of the macroinvertebrate response variables exhibited an interaction effect of time period and day (Table 3).

As part of our between-riffles analysis we documented 11 taxa from 76 captures within the impacted riffle and 14 taxa from 324 captures within the unimpacted riffle (Table 4). The three most commonly occurring taxa in the impacted riffle were Nematoda, Chironomidae, and Baetidae, while the three most commonly occurring taxa in the unimpacted riffle were Chironomidae, Nematoda, and Oligochaeta (Table 4$)$. We observed a difference $(\mathrm{P}<0.05)$ in 
Table 2. Abundance, percentage, and frequency of occurrences of each macroinvertebrate taxa captured within a riffle subjected to repeated disturbance by outdoor education stream classes in Alum Creek, Ohio from 19 May to 23 May 2014.

\begin{tabular}{|c|c|c|c|}
\hline Taxa & Abundance & Percentage & Frequency \\
\hline Nematoda (nematodes) & 507 & 51.3 & 5 \\
\hline Chironomidae (non-biting midges) & 160 & 16.2 & 5 \\
\hline Baetidae (small minnow mayflies) & 112 & 11.3 & 5 \\
\hline Plecoptera (stoneflies) & 49 & 5.0 & 5 \\
\hline Oligochaeta (segmented worms) & 32 & 3.2 & 5 \\
\hline Heptageniidae (flatheaded mayflies) & 29 & 2.9 & 5 \\
\hline Turbellaria (flat worms) & 26 & 2.6 & 4 \\
\hline Psephenidae (water pennies) & 16 & 1.6 & 5 \\
\hline Simuliidae (black flies) & 16 & 1.6 & 5 \\
\hline Elmidae (riffle beetles) & 11 & 1.1 & 5 \\
\hline Chaoboridae (phantom midges) & 4 & 0.4 & 1 \\
\hline Hydracarina (water mites) & 4 & 0.4 & 2 \\
\hline Caenidae (small squaregill mayflies) & 3 & 0.3 & 3 \\
\hline Leptophlebiidae (pronggilled mayflies) & 3 & 0.3 & 1 \\
\hline Zygoptera (damselflies) & 3 & 0.3 & 3 \\
\hline Asellidae (sowbugs) & 2 & 0.2 & 2 \\
\hline Cambaridae (crayfishes) & 2 & 0.2 & 2 \\
\hline Tipulidae (crane flies) & 2 & 0.2 & 1 \\
\hline Ceratopogonidae (biting midges) & 1 & 0.1 & 1 \\
\hline Collembola (springtails) & 1 & 0.1 & 1 \\
\hline Helicopsychidae (snailcase caddisflies) & 1 & 0.1 & 1 \\
\hline Hemiptera (true bugs) & 1 & 0.1 & 1 \\
\hline Pleuroceridae (Pleurocerid snails) & 1 & 0.1 & 1 \\
\hline Sphaeridae (fingernail clams) & 1 & 0.1 & 1 \\
\hline Trichoptera (caddisflies) & 1 & 0.1 & 1 \\
\hline
\end{tabular}

Table 3. $\mathrm{P}$ values from a two factor generalized linear model analysis and two factor analysis of variance conducted to determine if aquatic macroinvertebrate community response variables differed between time periods (morning and afternoon) or among days within a riffle subjected to repeated disturbance by outdoor education stream classes in Alum Creek, Ohio from 19 May to 23 May 2014.

\begin{tabular}{cccc}
\hline Response variable & Time period & Day of week & Time $\times$ Day interaction effect \\
\hline Macroinvertebrate abundance & 0.771 & 0.327 & 0.146 \\
Taxa richness & 0.570 & 0.913 & 0.887 \\
EPT abundance & 0.603 & 0.166 & 0.339 \\
Percent EPT & 0.237 & 0.544 & 0.856 \\
Shannon diversity & 0.436 & 0.979 & 0.850 \\
Evenness & 0.442 & 0.985 & 0.522 \\
Clinger abundance & 0.899 & 0.152 & 0.223 \\
Percent clingers & 0.486 & 0.428 & 0.825 \\
DVF clinger abundance & 0.937 & 0.567 & 0.554 \\
\hline
\end{tabular}


Table 4. Number (\%) of each macroinvertebrate taxa captured within an impacted riffle subjected to repeated disturbance by outdoor education stream classes and an unimpacted riffle in Alum Creek, Ohio sampled at the start of sampling on Monday 19 May 2014 and the end of sampling on Friday 23 May 2014.

\begin{tabular}{|c|c|c|}
\hline Taxa & Impacted & Unimpacted \\
\hline Nematoda (nematodes) & $21(27.6)$ & $101(31.2)$ \\
\hline Chironomidae (non-biting midges) & $19(25.0)$ & $112(34.6)$ \\
\hline Baetidae (small minnow mayflies) & $12(15.8)$ & $21(6.5)$ \\
\hline Plecoptera (stoneflies) & $7(9.2)$ & $8(2.5)$ \\
\hline Heptageniidae (flatheaded mayflies) & $3(3.9)$ & $19(5.9)$ \\
\hline Leptophlebiidae (pronggilled mayflies) & $3(3.9)$ & $0(0.0)$ \\
\hline Oligochaeta (segmented worms) & $3(3.9)$ & $42(13.0)$ \\
\hline Psephenidae (water pennies) & $3(3.9)$ & $5(1.5)$ \\
\hline Simuliidae (black flies) & $3(3.9)$ & $0(0.0)$ \\
\hline Tipulidae (crane flies) & $1(1.3)$ & $0(0.0)$ \\
\hline Turbellaria (flat worms) & $1(1.3)$ & $0(0.0)$ \\
\hline Anisoptera (dragonflies) & $0(0.0)$ & $1(0.3)$ \\
\hline Caenidae (small squaregill mayflies) & $0(0.0)$ & $1(0.3)$ \\
\hline Elmidae (riffle beetles) & $0(0.0)$ & $9(2.8)$ \\
\hline Hydracarina (water mites) & $0(0.0)$ & $1(0.3)$ \\
\hline Isonychiidae (brushlegged mayflies) & $0(0.0)$ & $2(0.6)$ \\
\hline Pleuroceridae (Pleurocerid snails) & $0(0.0)$ & $1(0.3)$ \\
\hline Zygoptera (damselflies) & $0(0.0)$ & $1(0.3)$ \\
\hline
\end{tabular}

macroinvertebrate abundance and DVF clinger abundance between riffles (Table 5). Macroinvertebrate abundance and DVF clinger abundance were greater at the unimpacted riffle than the impacted riffle (Figure 1). There was no difference $(P>0.05)$ between days and no significant interaction effect of day $\mathrm{x}$ site for macroinvertebrate abundance or DVF clinger abundance (Table 5). We also observed a difference $(P<0.05)$ in evenness between riffles (Table 5$)$, with greater evenness within the impacted riffle than the unimpacted riffle (Figure 1). A significant day $\mathrm{x}$ site interaction effect occurred for percent clingers that indicated the effect of day was different between riffles (Table 5). The percent clingers within the impacted riffle was greater $(\mathrm{P}<0.05)$ at the start of sampling on Monday morning than at the end of sampling on Friday afternoon, while the percent clingers in the unimpacted riffle was greater $(\mathrm{P}<0.05)$ at the end of sampling on Friday afternoon than the beginning of sampling on Monday morning (Figure 2). No difference $(P>0.05)$ in taxa richness, EPT abundance, percent EPT, Shannon diversity, or clinger abundance occurred between days or between sites (Table $5)$. 
Table 5. $\mathrm{P}$ values from a two factor generalized linear model analysis and two factor analysis of variance conducted to determine if aquatic macroinvertebrate community response variables differed between days (Monday and Friday) and sites (a riffle impacted by repeated disturbance from outdoor education stream classes and an unimpacted riffle) within Alum Creek, Ohio on 19 May and 23 May 2014. Bolded P values are those that were $<0.05$.

\begin{tabular}{cccc}
\hline Response Variable & Day & Site & Day $\times$ Site Interaction Effect \\
\hline Macroinvertebrate abundance & 0.914 & $<0.001$ & 0.877 \\
Taxa richness & 0.460 & 0.107 & 0.539 \\
EPT abundance & 0.242 & 0.141 & 0.628 \\
Percent EPT & 0.289 & 0.050 & 0.141 \\
Shannon diversity & 0.549 & 0.932 & 0.285 \\
Evenness & 0.772 & $<0.001$ & 0.730 \\
Clinger abundance & 0.552 & 0.080 & 0.237 \\
Percent clingers & 0.934 & 0.178 & 0.039 \\
DVF clinger abundance & 0.317 & $\mathbf{0 . 0 3 9}$ & 0.258 \\
\hline
\end{tabular}
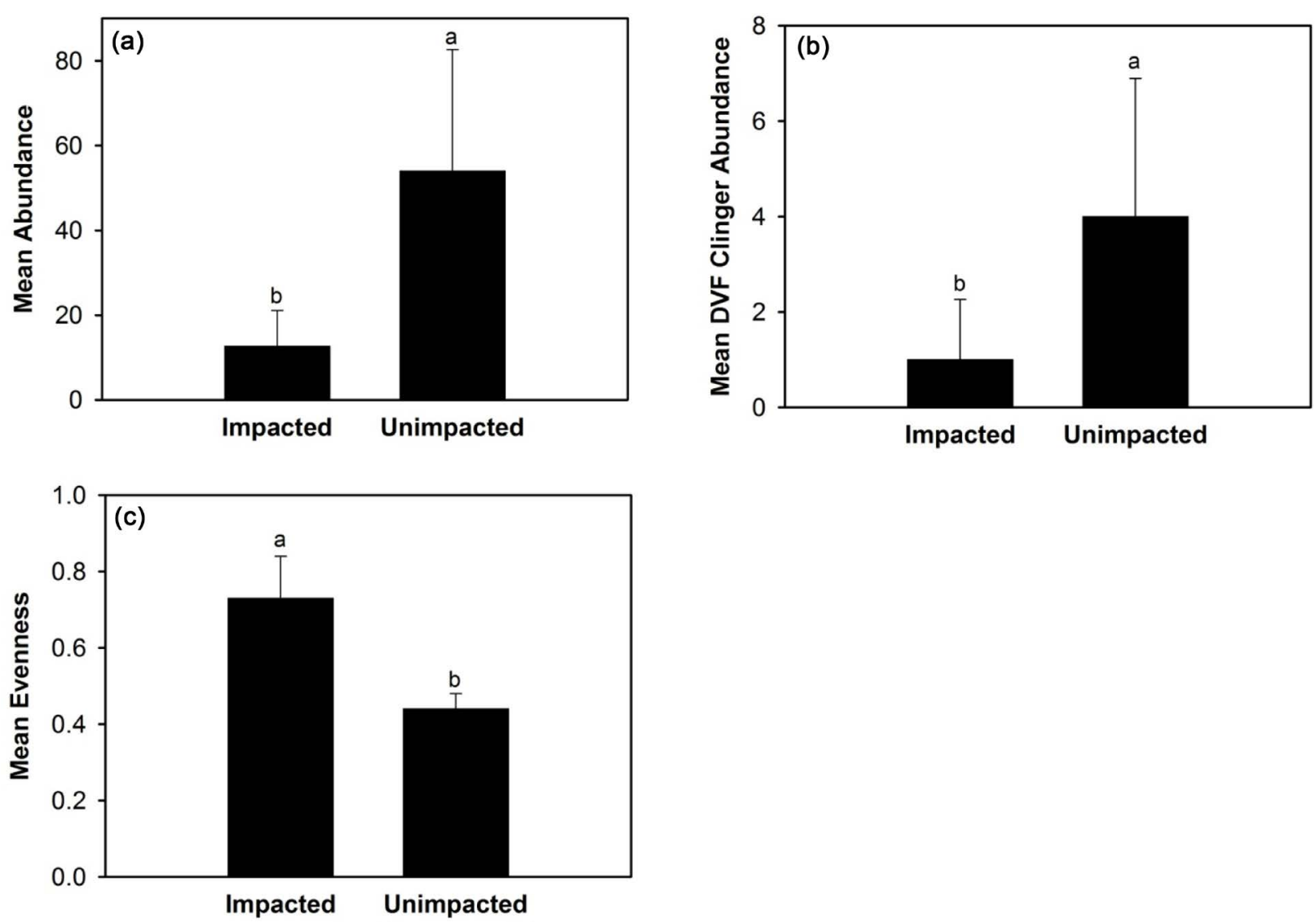

Figure 1. Mean macroinvertebrate abundance (a), mean dorsoventrally flattened (DVF) clinger abundance (b), and mean evenness $\left(\mathrm{E}_{1 / \mathrm{D}},(\mathrm{c})\right)$ within an impacted riffle disturbed by outdoor education stream classes and an unimpacted riffle in Alum Creek, Ohio 19 May and 23 May 2014. 

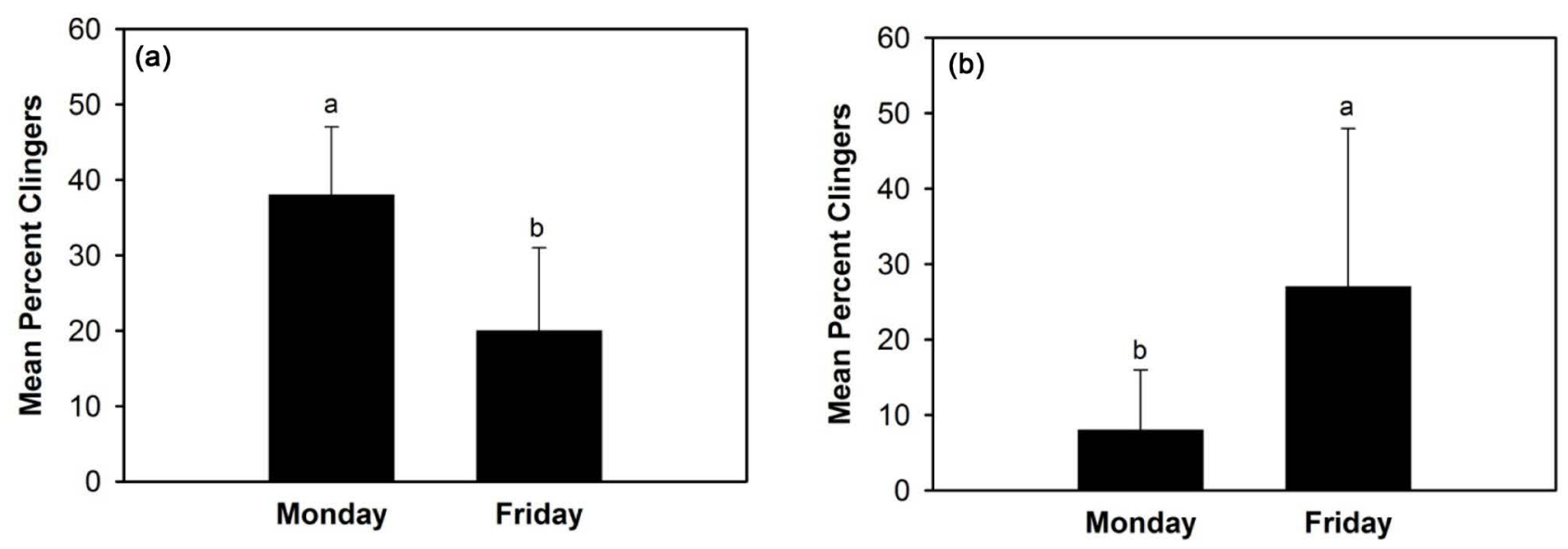

Figure 2. Mean percent clingers at the start of sampling Monday 19 May 2014 and the end of sampling on Friday 23 May 2014 within an impacted riffle disturbed by outdoor education stream classes (a) and an unimpacted riffle (b) in Alum Creek, Ohio.

\section{Discussion}

\subsection{Within-Riffle Assessment}

If student-induced disturbance occurred at the impacted riffle, we predicted that we would observe declines in macroinvertebrate abundance, richness, and diversity, as well as changes in the abundance of select guilds between the morning and afternoon samples and an increased negative response as the week progressed. This pattern did not manifest during our study, which suggests that intensive stream exploration activity by students in the impacted riffle during our study did not result in disturbance to the resident aquatic macroinvertebrates. Our results did not support the hypothesis that the macroinvertebrate community would exhibit a negative response to student-induced substrate disruption between morning and afternoon and among days. We expected to observe overnight recovery in the macroinvertebrate community each day due to macroinvertebrate drift and the ability of aquatic macroinvertebrates to recover relatively quickly following small-scale disturbances [3] [15]. However, we did not expect nightly recovery of the nine community response variables to reach the levels exhibited at the beginning of the study by each morning. The drift phenomenon is known to occur at night, particularly during dusk, apparently to avoid diurnal predators that rely upon light to see their prey [26] [27]. However, no clear pattern of diurnal decline or nocturnal recovery was observed during our five day study. The absence of change between time periods and among days in macroinvertebrate abundance or taxa richness within the impacted riffle contrasts with studies that have observed reductions in abundance and richness for disturbances conducted over intervals greater than one day [17] and for post-disturbance sampling periods conducted in intervals of one day or longer [18].

EPT taxa are known to be sensitive to chemical disturbance and are commonly used as water quality indicators in stream monitoring [21]. Since student-induced rock movement represents a potential physical disturbance rather than a chemical disturbance, it is not surprising that EPT-related response variables did not 
differ between time periods or among days during our study. In contrast, Laing [14] observed reduced EPT abundance during the summer (June to August) in tributaries of the Niobrara River in northern Nebraska disturbed by humans walking across the substrate when compared with similar undisturbed tributaries. However, Laing [14] did not observe a difference in EPT abundance between disturbed and undisturbed tributaries in May. This similarity between our results and Laing's [14] May results suggest that EPT responses to human activity may differ among seasons. Furthermore, EPT response to physical disturbance may relate more to the habit guild to which the taxa belong, rather than their taxonomic classification. Most Plecoptera and many Ephemeroptera are sprawlers and crawlers that may be more susceptible to physical disturbance than clingers. If the relative abundance of EPT sprawlers and crawlers is greater in summer months compared to EPT clingers, this may account for their seasonal responsiveness to physical disturbance.

Physical disturbance in the form of substrate rearrangement during spates is known to cause a decline in macroinvertebrate density and/or taxa richness [28] [29] [30] [31] [32]. However, spates not only cause movement of streambed rocks, they also increase the water velocity and discharge. Macroinvertebrates that get dislodged from the streambed during substrate movement in a spate are prone to being swept downstream by the increased stream power. This dual disturbance of substrate movement and increased water velocity does not occur as a result of student exploration of streams during outdoor education stream classes. Macroinvertebrates dislodged from the substrate during student-induced substrate disturbance may simply crawl or swim to another rock, drift to a neighboring patch, or retreat into the hyporheic zone. For example, Baetidae nymphs are quick, agile swimmers and have been observed to dart quickly from one patch to another when the stone under which they reside is removed (J. Bossley, personal observation). Macroinvertebrates that typically occupy the hyporheic zone may simply retreat further into the hyporheic zone upon sensing vibrations from students hiking on the streambed [31] or upon sensing a change in water velocity caused by rearrangement of rocks.

We evaluated three clinger response variables (clinger abundance, percent clingers, and DVF clinger abundance) because of their anticipated tolerance to physical disruption. Clingers that exhibit dorsoventral flattening of the body and/or possess claws that enable proficient clinging to the substrate may be able to resist being dislodged from a rock when it is moved or picked up out of the stream by a student. Clingers like Heptageniidae nymphs have been observed scurrying from one side of a rock to the other as it is inspected and turned (J. Bossley, personal observation). Slow moving clingers like Psephenidae larvae may simply remain in place if not discovered and removed from the rock. However, our results did not indicate whether clingers were more tolerant to disturbance caused by stream classes compared to other habit guilds.

An important consideration in interpreting the results of our within-riffle assessment is the catch and release policy that Heartland Outdoor School main- 
tains for their stream classes. All organisms captured during each stream class are released back into the water at the left edge of the stream at the impacted riffle. Although some macroinvertebrates inevitably incur injury or death during each class, most are safely released back into the riffle (J. Bossley, personal observation), where they have opportunity to recolonize before the next class begins. This observation contrasts with Clifford's [33] report that most organisms captured after experimental disturbance of streambed patches were severely damaged or dead. However, the substrate in Clifford's [34] stream consisted of fine particles (mean width $=1.7 \mathrm{~mm}$ ) and was vigorously disturbed with rakes, hoes, and shuffling of feet down to the hardpan. In Alum Creek the substrate is primarily coarse gravel (width $=32-64 \mathrm{~mm}$ ) with numerous cobbles affording greater refugia via greater rock surface area and larger pore spaces in the gravel. Also, the student-induced substrate disturbance and macroinvertebrate collection methods used as part of Heartland Outdoor School's stream classes is likely less disruptive to the substrate than the experimental substrate disturbance implemented as part of Clifford's [33] study.

Since most captured macroinvertebrates are safely released back into the stream, they have opportunity to redistribute throughout the riffle. Typically, the interim period from the time one class leaves the stream until the next class enters the stream is 30 to 45 minutes. This is likely a sufficient period for swimming organisms such as Cambaridae, Odonata, and Baetidae to disperse into the stream and find a new suitable location. It has been reported that some Baetis spp. are capable of reaching post-disturbance abundance levels on experimental substrate within one day [17]. Even some Tipulidae, while burrowers by nature, possess adequate swimming ability to disperse into a more suitable part of the stream. Slower moving crawlers and clingers such as Heptageniidae, Leptophlebiidae, Psephenidae, and Elmidae larvae are likely to drift downstream upon release or find a nearby rock on which to attach. Burrowing or clinging organisms such as Chironomidae and Simuliidae are also likely to either drift downstream, return to the hyporheic zone, or attach to a rock near the release point.

Students moving throughout the impacted riffle, overturning rocks, and moving rocks during stream classes resulted in the substrate within the impacted riffle being disturbed in a patchy manner [16]. Since the impacted riffle consists of similar substrate throughout the entire riffle, only fine-grained differences in substrate disturbance occurs among patches within the riffle. Released macroinvertebrates, drifting macroinvertebrates from upstream, and macroinvertebrates able to avoid capture are free to continuously redistribute [34] throughout patches within the impacted riffle, limited only by their own size and mobility and whatever dispersal barriers those may convey [35].

Future research should examine whether the composition of habit guilds changes among different patches within the impacted riffle during the course of a day or week as classes continue to remove and release organisms because of the potential cumulative disturbance effect of classes throughout the day. It is possi- 
ble that the frequent catch and release of macroinvertebrates by students occurs at a faster rate than the macroinvertebrates can redistribute themselves. We did not document a decline in clingers within the impacted riffle during the study, but this could reflect clingers' ability to avoid detection or remain attached even if their rocks were removed from the stream and examined. If clingers were difficult to see and collect from rocks at the start of the week they would still be equally difficult to see and collect at the end of the week, resulting in no cumulative decline throughout the week. This may be especially true for Psephenidae larvae, since they are DVF clingers that are often well-camouflaged against sandstone rocks as they typically remain nearly or entirely still when the rock to which they are attached is temporarily removed from the stream by a student. Sprawlers and crawlers such as Plecoptera are more likely to be seen and removed from a rock when inspected by a student because of their tendency to move in response to the rock being removed from the water. Also, crawlers are more likely to be knocked loose from rocks during disturbance of the substrate when a kick seine is used because of their reduced clinging ability compared to clingers. Consequently, a disturbance regime induced by students may lead to a shift in sprawlers and crawlers throughout the day or week from the right and center sides of the riffle where they are collected toward the left side of the riffle where these organisms are released after each class. Alternatively, the tendency for non-movement and DVF body form that Psephenidae exhibit may not be an advantage to them in avoiding detection by students, so a student-induced disturbance regime may also lead to an increase in clingers and DVF clingers on the left side of the riffle.

\subsection{Between-Riffle Assessment}

For the between-riffles assessment, we predicted that no significant change in macroinvertebrate community structure would occur from the start of sampling on Monday morning to the end of sampling on Friday afternoon at the unimpacted riffle, while a cumulative decline in the macroinvertebrate community structure was expected from the start of sampling on Monday morning to the end of sampling on Friday afternoon within the impacted riffle. Overall, our results did not support the hypothesis that the macroinvertebrate community in the impacted riffle would exhibit a negative response to student-induced substrate disruption from the start of sampling on Monday morning to the end of sampling on Friday afternoon, while the macroinvertebrate community in the unimpacted riffle remained unchanged.

Our results indicated that macroinvertebrate abundance was greater in the unimpacted riffle than the impacted riffle at the start of sampling on Monday morning before stream classes began and the end of sampling on Friday afternoon after stream classes ended for the week and suggests that student-induced disturbance as a result of outdoor education stream classes led to the observed abundance trends. Our finding that student-induced disturbance decreased macroinvertebrate abundance is consistent with the findings of other studies [13] 
[14] [15] that documented decreased macroinvertebrate abundance, density, and increased macroinvertebrate drift in response to human recreational activity. However, Caires et al. [15] also documented that benthic macroinvertebrate abundance did not differ among riffles subjected to different levels of disturbance by hikers. Caires et al. [15] explained their contradictory results by concluding that instream hiking increased macroinvertebrate drift, but it did not result in long-term impacts on macroinvertebrates because individuals from nearby undisturbed patches were able to recolonize the disturbed patches.

The observed difference in evenness between the riffles suggests that student-induced substrate disruption influenced the pattern of relative abundance of macroinvertebrate taxa within the impacted riffle. The relative abundance of larval Chironomidae, one of the top two most abundant taxa in both riffles, was ten percent greater in the unimpacted riffle than in the impacted riffle. The decreased relative abundance of Chironomidae within the impacted riffle concurs with the findings of Gafner and Robinson [36] who documented decreases in larval Chironomidae relative abundance with increasing disturbance within first order alpine streams in Switzerland. In contrast, larval Chironomidae relative abundance in streams within the United States typically increases within increasing disturbance [37] [38] [39]. Chironomidae larvae inhabiting upper Alum Creek during the spring are found most abundantly among the algae on rock surfaces (J. Bossley, personal observation). Perhaps the frequent student-induced substrate disturbance within the impacted riffle reduced Chironomid algal food sources and subsequently resulted in reduced abundance of Chironomidae larvae [16].

The greater DVF clinger abundance observed at the unimpacted riffle compared to the impacted riffle may be a reflection of the greater overall macroinvertebrate abundance at the unimpacted riffle. However, the difference $(\mathrm{P}<$ 0.05 ) in the temporal trends of percent clingers between riffles suggests that the difference in DVF clinger abundance between riffles is not simply a result of the difference in macroinvertebrate abundance between the riffles. The reduction in percent clingers from the start of sampling on Monday morning to the end of sampling on Friday afternoon within the impacted riffle is likely a result of the clingers' inability to reestablish at a faster rate than the substrate disruption occurs. The increase in clinger percentage from the beginning of sampling on Monday morning to the end of sampling on Friday afternoon within the unimpacted riffle may be attributed to the impact of sampling macroinvertebrates on Monday morning and the lack of student disruption of substrate throughout the rest of the week. Localized substrate disturbance within sampling quadrats on Monday morning in the unimpacted riffle may have opened these areas for colonization. Clingers from neighboring patches as well as drifters from upstream had sufficient time to recolonize the sampled plots by the end of the week and were able to do so without the interruption of student-induced substrate disturbance, which could have resulted in the observed increase in percent clingers within the 
unimpacted riffle.

Clingers, particularly DVF clingers, are better-suited to resist physical substrate disruption. Consequently, we anticipated that if aquatic macroinvertebrates exhibit differential response to student-induced disturbance based on habit guild, it may be revealed by a greater presence of clingers at the impacted riffle by the end of the week. However, the opposite trend occurred (Figure 2) within our results. This finding suggests that either rocks in the impacted riffle were thoroughly examined and picked by students such that clingers were unable to remain unseen and were as likely to be removed from rocks as other macroinvertebrates or the level of student-induced substrate disturbance throughout the week was enough to dislodge clingers and cause them to drift downstream. Clingers also appear to have been slower at recolonizing the impacted riffle than macroinvertebrates in other habit guilds, perhaps due to their reduced mobility and lesser ability to move upstream compared to crawlers and swimmers.

The differences in the macroinvertebrate community between the impacted riffle and unimpacted riffle may be due to the prolonged effect of student-induced rock movement at the impacted riffle. Heartland Outdoor School began using the impacted riffle for stream classes in 2010. Consequently, at the time this study was conducted, the impacted riffle had received five years of continuous use in the spring and autumn by outdoor education stream classes. We have also quantified that riffles subjected to outdoor education stream classes experience increased substrate disturbance by the students and subsequently reduced macroinvertebrate colonization compared to undisturbed riffles [16]. Thus, the observed difference in macroinvertebrate abundance, evenness, percent clingers, and DVF clinger abundance between impacted and unimpacted riffles likely reflects the frequent substrate disruption at the impacted riffle over time. Matthaei et al. [18] postulated that disturbance frequency may result in biotic consequences only if it persists over long durations (i.e., $>30$ days). Viewed on a seasonal or annual time scale, the repeated student-induced substrate disruption at the impacted riffle may have acted as a press disturbance.

Alternatively, the differences between riffles in macroinvertebrate abundance, evenness, percent clingers, and DVF clinger abundance may indicate that the unimpacted riffle consists of more suitable habitat allowing it to host a macroinvertebrate community containing more individuals, reduced evenness in relative abundance among different taxa, and greater numbers of clingers and DVF clingers. We did not measure water velocity and discharge during this study. However, both riffles were selected because they were qualitatively similar in wet width, amount of turbulent flow, degree of water surface broken by underlying substrate, and water depth. Our site selection criteria and the close proximity of the two riffles to each other (i.e., within $100 \mathrm{~m}$ ) suggests that hydrologic differences between riffles are not likely to result in the observed differences in macroinvertebrates. Additionally, visual assessment of the substrate at both riffles indicated similar substrate composition, which suggests that substrate type is not likely a 
potential cause for the observed difference in macroinvertebrate communities between riffles. We did not measure water chemistry during our study. However, EPT abundance and percent EPT did not differ between the impacted and unimpacted riffles. The sensitivity of EPT taxa to water chemistry conditions suggests that water chemistry conditions were similar at both riffles and likely did not lead to the observed differences in macroinvertebrate community structure between the impacted and unimpacted riffles.

No sampling was conducted in either riffle prior to 2010 when the stream class program was initiated, so information on the macroinvertebrate community within the riffles prior to student impact is not available. However, apparent similarities in hydrologic conditions, substrate type, and water chemistry between the unimpacted riffle and the impacted riffle suggest that differences in macroinvertebrate abundance, DVF clinger abundance, percent clingers, and evenness are due to prolonged effects of student-induced substrate rearrangement at the impacted riffle. Further study is needed to confirm these observations.

\section{Conclusion}

In conclusion, the absence of any clear decline and recovery pattern among the macroinvertebrate community during our study indicates that outdoor education stream classes did not lead to changes in aquatic macroinvertebrate community structure between time periods and among days at the within-riffle scale. We believe the lack of differences in community structure at the within-riffle scale resulted from the continuous redistribution of macroinvertebrates within and among patches within the impacted riffle. Over a longer time scale and at the between-riffle scale, our results indicate that the cumulative effects of outdoor education stream classes may have acted as a press disturbance and negatively impacted the biota within the impacted riffle. Our findings suggest that directors and administrative staff of outdoor education centers should be aware that their stream classes may negatively impact the macroinvertebrate communities. Directors and administrative staff of outdoor education centers should consider using multiple riffle sites in an alternating fashion for their educational efforts instead of using one riffle exclusively for stream classes to reduce the potential impacts of stream classes on aquatic macroinvertebrates.

\section{Acknowledgements}

We thank S. Fisher, R. Moore, K. Lekies, D. Denlinger, and an anonymous reviewer for helpful comments on an earlier draft of this manuscript. We also thank program manager A. Buzbee of Heartland Outdoor School for supporting the project and permission to access sites on the Heartland Outdoor School property for sampling. We thank H. Nguyen for providing guidance on statistical analyses. JPB was supported by a National Science Foundation Fellowship provided by the grant Linking Watershed Education with GK-12 Education in a Watershed Context. 


\section{References}

[1] Stanley, E.H., Powers, S.M. and Lottig, N.R. (2010) The Evolving Legacy of Disturbance in Stream Ecology: Concepts, Contributions, and Coming Challenges. Journal of the North American Benthological Society, 29, 67-83.

https://doi.org/10.1899/08-027.1

[2] Pickett, S.T.A. and White, P.S. (1985) The Ecology of Natural Disturbance and Patch Dynamics. Academic Press, Orlando.

[3] Niemi, G.J., Devore, P., Detenbeck, N., Taylor, D., Lima, A., Pastor, J., Yount, J.D. and Naiman, R.J. (1990) Overview of Case Studies on Recovery of Aquatic Systems from Disturbance. Environmental Management, 14, 571-587. https://doi.org/10.1007/BF02394710

[4] Davis, A.K. (2007) Walking Trails in a Nature Preserve Alter Terrestrial Salamander Distributions. Natural Areas Journal, 27, 385-389. https://doi.org/10.3375/0885-8608(2007)27[385:WTIANP]2.0.CO;2

[5] Smith-Castro, J.R. and Rodewald, A.D. (2010) Effects of Recreational Trails on Northern Cardinals (Cardinalis cardinalis) in Forested Urban Parks. Natural Areas Journal, 30, 328-337. https://doi.org/10.3375/043.030.0308

[6] Weston, M.A., Schlacher, T.A. and Lynn, D. (2014) Pro-Environmental Beach Driving Is Uncommon and Ineffective in Reducing Disturbance to Beach-Dwelling Birds. Environmental Management, 53, 999-1004.

https://doi.org/10.1007/s00267-014-0256-4

[7] Santos, G.S., Burgos, D.C., Lira, S.M.A. and Schwamborn, R. (2015) The Impact of Trampling on Reef Macrobenthos in Northeastern Brazil: How Effective Are Current Conservation Strategies? Environmental Management, 56, 847-858. https://doi.org/10.1007/s00267-015-0552-7

[8] Guo T., Smith, J.W., Leung, Y.F., Seekamp, E. and Moore, R.L. (2015) Determinants of Responsible Hiking Behavior: Results from a Stated Choice Experiment. Environmental Management, 56, 765-776. https://doi.org/10.1007/s00267-015-0513-1

[9] Firehock, K., Marshall, L. and Pinto, I. (1995) Hands on Save Our Streams: The Save Our Streams Teacher's Manual. Izaak Walton League of America, Gaithersburg.

[10] Barrows, C.W. and Allen, M.F. (2007) Biological Monitoring and Bridging the Gap between Land Management and Science. Natural Areas Journal, 27, 194-197. https://doi.org/10.3375/0885-8608(2007)27[194:BMABTG]2.0.CO;2

[11] Willson, G.D., Narumalani, S., Lockert, C.K. and Merani, P.B.T. (2014) Application of Natural Resource Condition Assessments to Two Small National Parks. Natural Areas Journal, 34, 235-248. https://doi.org/10.3375/043.034.0214

[12] Falk, J.H. (1974) Estimating Experimenter-Induced Bias in Field Studies: A Cautionary Tale. Oikos, 25, 374-378. https://doi.org/10.2307/3543959

[13] Wright, K.K. and Li, J.L. (1998) Effects of Recreational Activities on the Distribution of Dicosmoecus gilvipes in a Mountain Stream. Journal of the North American Benthological Society, 17, 535-543. https://doi.org/10.2307/1468370

[14] Laing, K.D. (2008) Impacts of Human Physical Disturbance on Benthic Communities in Tributaries of the Niobrara National Scenic River. MS Thesis, University of Nebraska, Lincoln.

[15] Caires, A.M., Vinson, M.R. and Brasher, A.M.D. (2010) Impacts of Hikers on Aquatic Macroinvertebrates in the North Fork of the Virgin River, Utah. Southwestern Naturalist, 55, 551-557. https://doi.org/10.1894/JS-33.1 
[16] Bossley, J.P. (2016) Environmental Impact from Outdoor/Environmental Education Programs: Effects of Frequent Stream Classes on Aquatic Macroinvertebrates. PhD Dissertation, Ohio State University, Columbus.

[17] Robinson, C.T. and Minshall, G.W. (1986) Effects of Disturbance Frequency on Stream Benthic Community Structure in Relation to Canopy Cover and Season. Journal of the North American Benthological Society, 5, 237-248. https://doi.org/10.2307/1467711

[18] Matthaei, C.D., Uehlinger, U., Meyer, E.I. and Frutiger, A. (1996) Recolonization by Benthic Invertebrates after Experimental Disturbance in a Swiss Prealpine River. Freshwater Biology, 35, 233-248. https://doi.org/10.1046/j.1365-2427.1996.00496.x

[19] Dole-Olivier, M.J., Marmonier, P. and Beffy, J.L. (1997) Response of Invertebrates to Lotic Disturbance: Is the Hyporheic Zone a Patch Refugium? Freshwater Biology, 37, 257-276. https://doi.org/10.1046/j.1365-2427.1997.00140.x

[20] Rosgen, D. (1996) Applied River Morphology. Wildland Hydrology. Pagosa Springs.

[21] US EPA (1997) Volunteer Stream Monitoring: A Methods Manual. Report 841-B-97-003, U.S. Environmental Protection Agency, Office of Water, Washington DC.

[22] Magurran, A.E. (2004) Measuring Biological Diversity. Blackwell Publishing, Malden.

[23] Smith, B. and Wilson, J.B. (1996) A Consumer's Guide to Evenness Indices. Oikos, 76, 70-82. https://doi.org/10.2307/3545749

[24] R Core Team (2015) R (Version 3.2.3): A Language and Environment for Statistical Computing. R Foundation for Statistical Computing, Vienna.

[25] Fox, J. and Weisberg, S. (2011) An R Companion to Applied Regression. Sage Publishing, Thousand Oaks.

[26] Williams, D.D. and Hynes, H.B.N. (1976) The Recolonization Mechanisms of Stream Benthos. Oikos, 27, 265-272. https://doi.org/10.2307/3543905

[27] Sagar, P.M. and Glova, G.J. (1992) Invertebrate Drift in a Large, Braided New Zealand River. Freshwater Biology, 27, 405-416. https://doi.org/10.1111/j.1365-2427.1992.tb00550.x

[28] Cobb, D.G., Galloway, T.D. and Flanagan, J.F. (1992) Effects of Discharge and Substrate Stability on Density and Species Composition of Stream Insects. Canadian Journal of Fisheries and Aquatic Sciences, 49, 1788-1795. https://doi.org/10.1139/f92-198

[29] Boulton, A.J., Peterson, C.G., Grimm, N.B. and Fisher, S.G. (1992) Stability of an Aquatic Macroinvertebrate Community in a Multiyear Hydrologic Disturbance Regime. Ecology, 73, 2192-2207. https://doi.org/10.2307/1941467

[30] Downes, B.J., Lake, P.S., Glaister, A. and Webb, J.A. (1998) Scales and Frequencies of Disturbances: Rock Size, Bed Packing and Variation among Upland Streams. Freshwater Biology, 40, 625-639. https://doi.org/10.1046/j.1365-2427.1998.00360.x

[31] Matthaei, C.D., Arbuckle, C.J. and Townsend, C.R. (2000) Stable Surface Stones as Refugia for Invertebrates During Disturbance in a New Zealand Stream. Journal of the North American Benthological Society, 19, 82-93. https://doi.org/10.2307/1468283

[32] Death, R.G. (2003) Spatial Patterns in Lotic Invertebrate Community Composition: Is Substrate Disturbance Actually Important? Canadian Journal of Fisheries and Aquatic Sciences, 60, 603-611. https://doi.org/10.1139/f03-052

[33] Clifford, H.F. (1982) Effects of Periodically Disturbing a Small Area of Substratum 
in a Brown-Water Stream of Alberta, Canada. Freshwater Invertebrate Biology, 1, 39-47. https://doi.org/10.2307/3259453

[34] Peckarsky, B.L. (1986) Colonization of Natural Substrates by Stream Benthos. Canadian Journal of Fisheries and Aquatic Sciences, 43, 700-709.

https://doi.org/10.1139/f86-085

[35] Gore, J.A. and Milner, A.M. (1990) Island Biogeographical Theory: Can It Be Used to Predict Lotic Recovery Rates? Environmental Management, 14, 737-753. https://doi.org/10.1007/BF02394722

[36] Gafner, K. and Robinson, C.T. (2007) Nutrient Enrichment Influences the Responses of Stream Macroinvertebrates to Disturbance. Journal of the North American Benthological Society, 26, 92-102. https://doi.org/10.1899/0887-3593(2007)26[92:NEITRO]2.0.CO;2

[37] Barbour, M.T., Gerritsen, J., Snyder, B.D. and Stribling, J.B. (1999) Rapid Bioassessment Protocols for Use in Streams and Wadeable Rivers: Periphyton, Benthic Macroinvertebrates and Fish. Second Edition, EPA 841-B-99-002, U.S. Environmental Protection Agency, Washington DC.

[38] Hutchens Jr., J.J., Schuldt, J.A., Richards, C., Johnson, L.B., Host, G.E. and Breneman, D.H. (2009) Multi-Scale Mechanistic Indicators of Midwestern USA Stream Macroinvertebrates. Ecological Indicators, 9, 1138-1150.

[39] Smiley Jr., P.C., King, K.W. and Fausey, N.R. (2010) Public Health Perspectives of Channelized and Unchannelized Headwater Streams in Central Ohio: A Case Study. Journal of Water and Health, 8, 577-592. https://doi.org/10.2166/wh.2010.160 